\title{
Analisis Penerapan Metode "Non-Value Added Activity Ellimination (Novaceli)" pada Organisasi Nir Laba di Lingkungan GKI
}

\author{
Analysis of the "Non-Value Added Activity Elimination (Novaceli)" Method in \\ Non-Profit Organizations within GKI
}

\author{
Rudy Wawolumaja ${ }^{1 *}$, Santoso ${ }^{2}$, Winda Halim ${ }^{3}$, Vania Carolina ${ }^{4}$ \\ 1,2,3,4 Program Studi Teknik Industri, Universitas Kristen Maranatha, Bandung \\ *Penulis korespondensi: Rudy Wawolumaja, rudy.wawolumaja@eng.maranatha.edu
}

\begin{abstract}
Abstrak
"Non Value Added Activity Elimination (NOVACELI)" dalam bahasa Indonesia berarti menghilangkan kegiatan yang tidak menambah nilai, istilah yang digunakan dalam penelitian ini yaitu merupakan suatu metoda yang dikembangkan untuk lingkungan organisasi manufaktur untuk menghilangkan pemborosan sumber daya. Penelitian ini ditujukan untuk memperluas penerapan metode NOVACELI dilingkungan organisasi non manufaktur, yaitu lingkungan organisasi jasa orientasi laba dan lingkungan organisasi nir laba (non) komersial. Penelitian ini dilakukan untuk menjawab pertanyaan yaitu bagaimana sebaiknya "non value added activity elimination" untuk organisasi jasa nir laba.

Untuk menjawab pertanyaan tersebut, penelitian dilakukan dengan menggunakan pendekatan Penelitian Kualitatif (Qualitative Research) dengan metoda pengumpulan data dengan pengamatan, tinjauan pustaka, tinjauan dokumen wawancara, Focus Group Discussion. Organisasi nirlaba yang menjadi sampel adalah organisasi gereja setempat dan universitas Kristen Maranatha. Pengamatan dilakukan secara pengamatan Peserta Kuasi (Quasi Partisipant), yaitu peneliti pada suatu rentang waktu melibatkan diri dalam aktivitas yang diamati. untuk memperkuat validitas penelitian, digunakan kombinasi triangulasi yaitu triangulasi data dan triangulasi investigator.

Dalam penelitian ini penciptaan dan evaluasi kegiatan dibagi dalam dua strata, yaitu strata strategis dan strata operasional. Hasil penelitian ini menyimpulkan untuk organisasi gereja setempat, pada strata strategis tema metode Novaceli tidak relevan dan untuk strata operasional metode Novaceli untuk industri jasa dapat diterapkan, yaitu pada kegiatan pelayanan administrasi dan kebutuhan surat keterangan bagi jemaat. Untuk organisasi Yayasan (YPTKM), metode Novaceli untuk industri jasa yang telah dikembangkan dapat diterapkan pada dibidang kesekertariatan, atau pelayanan administratif kesekretariatan pada direktorat pelaksana Yayasan dan tidak sesuai untuk kegiatan yayasan yang lain. Untuk organisasi Universitas Kristen Maranatha, maka untuk penciptaan dan evaluasi kegiatan pada strata strategis, juga penghilangan kegiatan yang tidak menambah nilai (novaceli), maka metode yang perlu dikembangkan adalah metode dalam manajemen strategi, yang menghasilkan rencana strategi, eksekusi dan evaluasi strategi. Sedangkan untuk strata operasional, seperti badan administrasi akademik, keuangan dan Sumber Daya manusia metode novaceli yang sudah dikembangkan untuk organisasi jasa komersial bisa diterapkan.
\end{abstract}

Kata kunci: limbah, novaceli, organisasi nir laba

\footnotetext{
Abstract

"Non Value Added Activity Elimination (NOVACELI)" in Indonesian means eliminating activities that do not add value, the term used in this study is a method developed for the manufacturing organization environment to eliminate waste of resources. This research is intended to expand the application of the NOVACELI method in non-manufacturing organizations, namely, for-profitoriented service organizations and non-commercial (non-profit) organizations. This research was conducted to answer the question, how should "non-value added activity elimination" be used for non-profit service organizations.
} 
To answer this question, the research was conducted using a Qualitative Research approach with data collection methods by observation, literature review, interview document review, Focus Group Discussion. The non-profit organizations that were sampled were local church organizations and Maranatha Christian university. Observations were made by observing Quasi Participant (Quasi Participant), ie researchers at a certain time involved themselves in the activities being observed. To strengthen the validity of the study, a combination of triangulation was used, namely data triangulation and investigator triangulation.

In this study the creation and evaluation of activities is divided into two strata, namely the strategic strata and operational strata. The results of this study conclude that for local church organizations, the Novaceli method theme is irrelevant for strategic strata and for operational strata the Novaceli method for the service industry can be applied, namely to administrative service activities and the need for certificates for the congregation. For Foundation organizations (YPTKM), the Novaceli method for the service industry that has been developed can be applied to the secretarial field, or secretarial administrative services at the Foundation's implementing directorate and is not suitable for other foundation activities. For the Maranatha Christian University organization, for the creation and evaluation of activities at strategic strata, as well as the elimination of activities that do not add value (novaceli), the method that needs to be developed is the method in strategic management, which produces strategic plans, execution and evaluation of strategies. Meanwhile, for operational strata, such as academic administration bodies, finance and human resources, the novaceli method that has been developed for commercial service organizations can be applied.

Keywords: not-for-profit organization, novaceli, waste

Informasi Artikel:

Diterima tanggal 8 Agustus 2021; Disetujui tanggal 4 Desember 2021; Terbit online tanggal 30 Desember 2021

\section{Pendahuluan}

Peningkatan produktivitas dan efisiensi dalam kegiatan manufaktur sudah berkembang dan baik metoda dan alatnya sudah sangat kuat, bisa dikatakan ke ilmuan Teknik Industri yang berkembang sejak 1950 an ke atas berfokus pada kegiatan manufaktur yang komersial. Namun untuk bidang kegiatan organisasi nir laba, masih terdapat ketidakefisienan, ketidakefektifan. Di Indonesia sangat kasat mata ketidak efisienan pelayanan publik pemerintahan dalam mengurus perijinan, yang bisa memakan waktu yang tidak masuk akal, bila dibandingkan dengan pelayanan yang sama dinegara maju lainnya. Untuk industri jasa seperti rumah sakit atau kesehatan/praktek dokter terlihat bagaimana pasien harus menunggu berjam-jam untuk mendapatkan pelayanan.

Dalam penelitian-penelitian terdahulu $[1,7,8,9,10,11,13,20,21]$ terdapat metode untuk menghilangkan pemborosan sumber daya yang dalam penelitian ini dinamakan "Non Value Added Activity Elimination" (Novaceli) yang pada hakekatnya adalah mengurangi atau menghilangkan waktu, proses, biaya.

Alat-alat yang tersedia sudah tersedia dalam ilmu Teknik Industri $[2,3,14,16,17]$, baik dalam perancangan tata letak, ilmu \& rekayasa kualitas, optimasi sistem produksi, penelitian operasi dan lainnya. Namun untuk kegiatan non manufaktur maupun kegiatan non komersial penerapan baik metoda maupun alat-alat untuk manufaktur tidak bisa sepenuhnya diterapkan, perlu peninjauan ulang dan mungkin pengembangan dan penyesuaian baik dalam metoda, alat mengingat perbedaan paradigma mendasar antara kegiatan manufaktur komersial dengan kegiatan non-manufaktur baik yang komersial maupun non komersial. Dalam organisasi non komersial perlu ditinjau tolok ukur nilai yang oleh metoda sebelumnya selalu mengacu pada dimensi nilai uang. 
Penelitian ini dilakukan dalam rangka meninjau ulang secara mendasar, mana yang bisa diterapkan, mana yang perlu dikembangkan dari metoda dan alat-alat yang sudah ada.

Metode menghilangkan pemborosan sumber daya merupakan suatu metoda yang cukup berhasil dalam Manajemen Ramping pada lingkungan organisasi manufaktur [2,3,12].

Pada lingkungan manufaktur, produk yang dihasilkan berupa produk berwujud berorientasi komersial mempunyai tolok ukur nilai yang universal dalam setiap organisasi manufaktur, yaitu nilai biaya, atau waktu atau jarak tempuh yang bisa diterjemahkan dalam nilai uang.

Pada lingkungan organisasi jasa komersial, metoda yang sudah ada untuk organisasi manufaktur sebagian bisa digunakan karena mempunyai tolok ukur nilai yang sama yaitu nilai uang, namun ada juga tolok ukur nilai yang ingin dihasilkan yaitu berupa nilai tidak berwujud. Sehingga metoda ini perlu dikembangkan disesuaikan.

Pada lingkungan organisasi jasa non komersial, maka persoalan menjadi lebih rumit karena tolok ukur nilai yang berbeda yang dalam beberapa konteks bisa bertentangan dengan tolok ukur nilai komersial, sehingga perlu peninjauan ulang penerapan metoda yang sudah ada dengan lebih mendasar dan metoda yang baru.

\section{Tinjauan Pustaka}

2.1 Pengertian \& Konsep Kegiatan tidak menambah nilai-Non Value Added Activity (NVA)

Dalam filosofi Manajemen Ramping, semua kegiatan dalam suatu organisasi dikelompokkan ke dalam dua kategori:

- kegiatan menambah nilai / bernilai tambah atau Value Added (VA), dan

- kegiatan tidak menambah nilai atau Non Value Added (NVA).

Dalam konteks Manajemen Ramping, kegiatan VA dan NVA dilihat dari perspektif pelanggan. Aktivitas VA adalah aktivitas yang memberikan nilai tambah pada produk atau layanan. Pelanggan bersedia membayar untuk kegiatan tersebut yang dapat mengubah bentuk, kesesuaian, atau fungsi suatu produk atau layanan.

Di sisi lain, kegiatan NVA adalah tugas yang tidak meningkatkan bentuk atau fungsi produk. Contohnya adalah pengarsipan, menyalin, merekam, menunggu, menghitung, memeriksa, memeriksa, menguji, meninjau dan memperoleh persetujuan. Kegiatan NVA juga sering disebut sebagai "Pemborosan atau Waste". Kegiatan-kegiatan ini harus dihilangkan, disederhanakan atau dikurangi.

Dengan menangani pemborosan/waste dari proses bisnis awal ke akhir, perusahaan tidak hanya dapat meningkatkan nilai produk dan layanannya, namun juga dapat mencapai pengurangan biaya yang signifikan, memperkuat arus kas, dan keluar dari keterpurukan dengan profil yang lebih kuat dan lebih kompetitif .

\subsection{Tujuh Sumber Pemborosan/NVA}

Ada tujuh sumber "pemborosan" di lingkungan manufaktur. Penelitian telah menunjukkan bahwa dalam organisasi tipikal, sekitar $90 \%$ atau lebih dari semua kegiatan termasuk dalam NVA. Meskipun penjelasan dan contoh-contoh yang diberikan di bawah ini mungkin lebih relevan untuk industri manufaktur, konsep-konsep tersebut dapat diterapkan secara universal pada industri jasa juga.

Tujuh sumber limbah adalah:

1. Menunggu 
Ini adalah waktu diam yang dihasilkan dari menunggu bahan dan informasi, antrian barang atau pelanggan, pengiriman yang tertunda, waktu henti peralatan atau sistem dan sebagainya.

2. Pemrosesan berlebih

Ini hasil dari prosedur yang tidak perlu karena persyaratan pelanggan yang tidak terdefinisi, kurangnya komunikasi yang efektif, proses yang tidak perlu, proses persetujuan yang berlebihan, membuat salinan tambahan dan pelaporan yang berlebihan.

3. Cacat

yang meliputi: kesalahan, produk gagal yang harus dibuang, pengerjaan ulang produk cacat, penggantian, inspeksi ulang dan pengujian ulang. Penyebabnya adalah entri data yang salah, kualitas yang buruk, kontrol proses yang lemah, pelatihan yang tidak memadai, pemeliharaan yang kurang terencana dan kebutuhan pelanggan yang tidak dipahami.

4. Gerakan yang tidak perlu

Ini mengacu pada setiap pergerakan orang atau mesin yang tidak menambah nilai pada produk atau layanan. Penyebab umum adalah tata letak pabrik atau kantor yang buruk, penanganan ganda, metode kerja yang tidak konsisten, dan organisasi di tempat kerja yang buruk.

5. Transportasi

Ini mengacu pada pengangkutan komponen/bagian, bahan dan arsip atau dokumen di sekitar pabrik atau kantor. Penyebabnya adalah tata letak pabrik atau kantor yang buruk, peralatan dan stasiun kerja yang letaknya berjauhan, dan pemahaman yang buruk tentang aliran proses.

6. Kelebihan produksi

Ini terjadi ketika stasiun kerja menghasilkan terlalu banyak, terlalu dini dan lebih cepat dari yang dibutuhkan oleh proses selanjutnya. Penyebabnya termasuk tujuan yang tidak jelas, lead time yang berlebihan, dan prakiraan/peramalan yang ketinggalan zaman.

Untuk mengatasi hal tersebut, ukuran batch harus dikurangi agar sesuai dengan tingkat permintaan. Memproduksi dengan tepat sesuai permintaan pelanggan, tidak lebih.

7. Kelebihan persediaan

Ini terjadi ketika proses memiliki lebih banyak persediaan kerja daripada yang dibutuhkan untuk suatu pekerjaan. Penting untuk mengatasi kelebihan persediaan karena memiliki dampak besar pada arus kas.

\subsection{Menghilangkan Pemborosan}

Kemampuan untuk mengidentifikasi pemborosan dalam organisasi adalah langkah pertama menuju penghapusannya. Langkah selanjutnya adalah pemecahan masalah untuk mengurangi atau menghilangkan pemborosan. Teknik pemecahan masalah yang umum adalah dicari dari khazanah alat-alat yang telah ada atau mengembangkan yang baru.

\subsection{Menghilangkan NVA di Lingkungan Jasa}

Langkah menghilangkan atau mengurangi NVA/limbah/waste di organisasi jasa:

1. Identifikasi masalah, misalnya antrian terlalu panjang, waktu tunggu pelayanan terlalu lama, waktu penyelesaian layanan terlalu lama, hingga pelanggan harus pulang dan kembali hari hari berikutnya. Masalah ini dapat juga diperoleh dari survey, keluhan pelanggan dan pengamatan.

2. Pemetaan Proses dan Kegiatan (PPG)

PPG digunakan untuk memetakan proses yang ada di dalam suatu unit layanan jasa. Dengan PPG didapatkan gambar/peta urutan proses aliran informasi dan aliran material dalam unit layanan jasa.

PPG memudahkan identifikasi dimana terjadinya pemborosan dan klasifikasi kegiatan yang digolongkan VA, NVA, perlu tapi tidak menambah nilai, sehingga dapat diidentifkasi mana kegiatan tergolong limbah.

3. Analisis penyebab masalah dan bobot masalah. 
Bobot masalah ditentukan berdasarkan dampak serius yang ditimbulkan. Berbagai alat/tools dapat digunakan seperti Fishbone diagram, FTA (Fault Tree Analysis) dapat digunakan untuk menelusuri penyebab dari sebuah permasalahan yang terjadi.

4. Klasifikasi dan Pembobotan limbah.

Dari identifikasi aktivitas yang tergolong limbah dalam unit layanan dilakukan klasifikasi limbah, menurut 7 klasifikasi limbah: Menunggu, Pemrosesan berlebih, Cacat, Gerakan yang tidak perlu, Transportasi, Kelebihan produksi, Kelebihan persediaan. Pembobotan berdasarkan frekuensi kemunculan. Frekuensi didapat dari pengamatan.

5. Tahap Analisa dan Perbaikan

Dalam tahapan ini akan dilakukan analisa, yang intinya aktivitas tak menambah nilai atau limbah dihilangkan. Atau cara yang lebih kreatif proses dirancang ulang dengan penerapan sistem informasi dan teknologi informasi.

\section{Pertanyaan Penelitian:}

Bagaimana sebaiknya Novaceli (non value added activity ellimination) pada organisasi nir laba.

Menjawab pertanyaan penelitian yang dirumuskan dalam identifikasi masalah diatas dengan cara:

a. Memahami kegiatan menambah nilai (kegiatan VA) dilingkungan jasa nir-laba

b. Menginterpretasikan hasil yang didapatkan dari temuan lapangan.

c. Membangun kembali konsep kegiatan VA dan akhirnya juga menghilangkan NVA secara mendalam.

\section{Hasil dan Pembahasan}

\subsection{Uraian konsep, metode/rancangan penelitian}

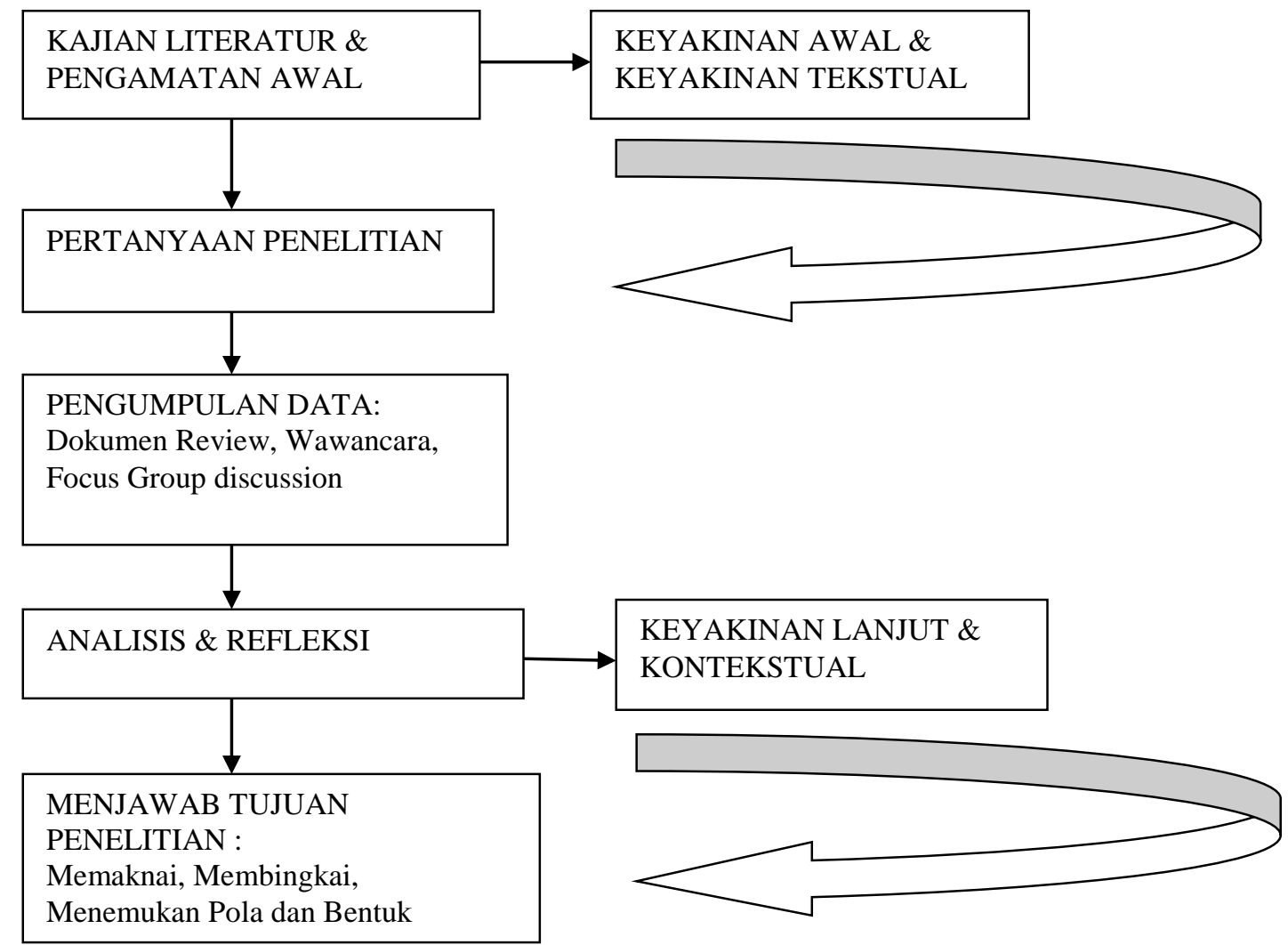

Gambar 1. Diagram alir penelitian 
Penelitian yang dilakukan adalah penelitian kualitatif, dengan tujuan memahami, menafsirkan dan membangun kembali konsep secara mendalam. Konsep yang didalami adalah konsep nilai yang dalam lingkungan nir laba (non komersial) masih abstrak dan membutuhkan interpretasi dalam konteksnya (kontekstual) dan belum memiliki definisi yang presisi dan belum memiliki indikator yang terukur dan konsep ini dinamis dalam arti dapat berkembang sesuai dengan konteksnya.

Langkah pertama penelitian dimulai dengan kajian tinjauan pustaka dan pengamatan awal. Tinjauan ini diawali dalam konteks organisasi laba (manufaktur khususnya), dimana konsep nilai, penambahan nilai, dan kegiatan yang menambah nilai sudah dapat di definisi kan dengan presisi dan diterjemahkan pada variabel-variabel seperti waktu, jarak, biaya dan pada akhirnya pada variabel nilai uang. Sehingga pada organisasi jenis ini dapat membentuk kerangka teori untuk memprediksi, menjelaskan dengan cukup presisi mana kegiatan yang tidak menambah nilai yang dapat dihilangkan. Kajian dilanjutkan pada organisasi jasa nir laba.

Langkah kedua adalah membentuk pertanyaan-pertanyaan penelitian. Berdasarkan pengamatan awal dan kajian literatur. Untuk organisasi nirlaba dibentuk pertanyaanpertanyaan penelitian yang dituangkan pada daftar pertanyaan-pertanyaan interview, pertanyaan-pertanyaan penelitian ini merupakan turunan dan rincian dari pertanyaan besar penelitian ini. Pertanyaan ini didasari oleh keyakinan subjektif peneliti dari pengamatan awal dan keyakinan tekstual sebagai hasil dari tinjauan dokumen dan literatur.

Langkah ketiga adalah pengumpulan data yang didapat dari observasi, wawancara (interview) dan atau Diskusi Kelompok Fokus (Focus Grup Discussion/FGD).

Langkah keempat adalah refleksi dari transkripsi data interview, FGD, Curah Pendapat untuk mendapatkan keyakinan kontekstual yang mungkin berbeda dari keyakinan tekstual dan keyakinan awal pengamatan yang didapat dari langkah kedua.

Langkah kelima adalah membentuk kesimpulan yang bersifat sementara dan dapat berkembang dengan penelitian lanjutan, sifat kesimpulan tidak definitif ini merupakan ciri khas dari penelitian kualitatif.

\subsection{Populasi, Sampel, Prosedur Metode Uji}

Populasi organisasi nir laba yang teridentifikasi adalah organisasi pemerintahan palayanan publik, organisasi militer, organisasi pelayanan kesehatan, organisasi karitatif, seperti yayasan rumah anak yatim piatu, yayasan rumah jompo, rumah sakit.

Organisasi nir laba yang diambil sebagai sampel adalah lingkungan organisasi gereja, seperti sinode GKI (Gereja Kristen Indonesia), dimana GKI selain pelayanan intinya adalah pelayanan kehidupan iman umatnya, juga memiliki beberapa Yayasan (nir laba) di bawahnya, seperti yayasan Pendidikan (Dasar, Menengah, Tinggi) seperti BPK Penabur, Universitas Krida Wacana, Universitas Kristen Maranatha. Yayasan Rumah Jompo, yatim Piatu dan yayasan karitatif lainnya.

Untuk wawancara dilakukan terhadap pimpinan/mantan pimpinan gereja setempat, pimpinan/mantan pimpinan klasis, pendeta, panatua, aktivis, anggota, pada pimpinan organisasi pendidikan di bawah GKI, unsur yayasan dan eksekutif, dan pimpinan/mantan pimpinan yayasan karitatif lainnya, seperti rumah jompo, rumah yatim piatu.

Sebagai metoda uji, peneliti melakukan triangulasi, Cohen dan Manion (2011) mendefinisikan triangulasi sebagai upaya untuk memetakan atau menjelaskan lebih lengkap, kekayaan dan kompleksitas perilaku manusia dengan mempelajarinya dari lebih dari satu sudut pandang. 
Tujuan triangulasi dalam penelitian kualitatif adalah untuk meningkatkan kredibilitas dan validitas hasil. Dalam penelitian ini peneliti menggunakan kombinasi dua tipe triangulasi untuk memperkuat validitas penelitian, yaitu triangulasi data dan triangulasi investigator. Dalam triangulasi data, peneliti melakukan konfirmasi penelitian pada waktu dan tempat yang berbeda-beda untuk menemukan suatu kebenaran (keyakinan). Berbeda waktu, yaitu pernyataan pada saat sendiri atau bersama-sama, beda orang, yaitu komentar dari banyak orang pada tingkatan yang sama atau berbeda. Dalam triangulasi investigator, peneliti memilih kolega yang juga melakukan pengamatan dan wawancara dan membandingkannya temuantemuan tersebut.

\subsection{Konteks Penelitian, Lokasi, Waktu, Tempat}

Konteks penelitian dibatasi di organisasi gereja sinode GKI dengan badan dan yayasan di bawahnya, lokasi dipilih di Bandung, namun wawancara dilakukan daring memungkinkan mencakup wilayah Jawa Barat.

Pengamatan dilakukan secara pengamatan Peserta Kuasi, yaitu peneliti pada suatu rentang waktu melibatkan diri dalam aktivitas yang diamati, dalam hal ini peneliti dapat merasakan yang dialami objek dan dapat mencatat lebih lengkap tentang aspek aspek yang diteliti. Rentang waktu observasi pribadi dari tahun 1985 - 2010, dimana peneliti adalah bagian dari anggota GKI yang pernah menjabat sebagai aktivis, panatua, pimpinan dilingkungan gereja dan pengurus dibeberapa yayasan dibawah GKI seperti BPK Penabur Bandung, yayasan YPTK Maranatha, pimpinan (Wakil Rektor) di UKMaranatha, Yayasan Kedukaan Bumi Baru. Pengalaman tersebut bisa menjadi pengamatan awal dalam membentuk keyakinan awal, sedangkan untuk membentuk keyakinan kontekstual maka konteks yang aktual akan didapat dengan wawancara dengan personil kunci yang berperan dalam periode aktual 2010-2020.

Pembahasan penelitian dipilah ke dalam kegiatan kehidupan bergereja dan kegiatan dalam lembaga di bawah sinode. Dalam diskusi kelompok fokus (FGD), terdapat silang pendapat apakah gereja dan lembaga di bawahnya itu organisasi nir laba, "apakah tidak sebaiknya dimulai dengan pengakuan bahwa organisasi tersebut adalah organisasi yang orientasi laba". Wacana tersebut muncul dari pengamatan pengelolaan lembaga pendidikan yang dianggap sangat lugas urusan bisnis, layaknya organisasi yang orientasi pada laba. Dan di sekolahsekolah lingkungan GKI yaitu BPK Penabur, disinyalir peserta didik mayoritas adalah warga di luar GKI. Proses penerimaan siswa baru mengikuti persaingan kompetensi akademis, juga kontribusi finansial pada sekolah. Jadi perlu di definisi kan lebih presisi apa yang dimaksud dengan organisasi nir laba.

Menurut PSAK No.45 (Pernyataan Standard Akuntansi Keuangan) pengertian dari organisasi Nir Laba adalah " organisasi yang memperoleh sumber daya yang berasal dari sumbangan pihak anggota. Para penyumbang ini tidak mengharapkan keuntungan materi yang akan diperoleh pada saat organisasi ini berkembang". Namun perkembangan selanjutnya, organisasi ini menerima hasil pendapatan jasa yang diberikan publik atau dari kegiatan investasi.

Bisa juga didefinisikan Organisasi nir laba adalah sekumpulan anggota yang bekerja sama dengan tujuan bukan keuntungan keuangan atau materi, untuk suatu tujuan yang dianggap mulia, seperti nilai keagamaan, nilai kemanusiaan. Kepuasan anggotanya bukan pada keuntungan materi atau finansial, namun berdasarkan prestasi dan capaian yang dianjurkan nilai mulia di luar nilai finansial. Organisasi nir laba mempunyai ciri yang membedakan dengan organisasi laba, yaitu bersifat sukarela dan anggotanya diharapkan bekerja maksimal meskipun tidak mendapat gaji atau imbalan. 
Menurut PSAK no 45 ciri-ciri organisasi nir laba adalah sebagai berikut:

- Sumber daya utamanya berasal dari penyumbang yang tidak mengharapkan laba atau keuntungan yang sebanding dengan sumber daya yang mereka korbankan.

- Organisasi tersebut mampu menghasilkan barang dan jasa tanpa bertujuan untuk menuntut laba dan keuntungan. Jika organisasi/entitas menghasilkan laba maka nominalnya tidak akan pernah dibagikan kepada penyumbang atau pemilik entitas.

- Di organisasi ini tidak ada kepemilikan yang jelas seperti organisasi lain. Artinya organisasi nir laba tidak dapat dijual, dialihkan atau dikembalikan sumbangannya. Pada dasarnya organisasi ini tidak mencerminkan adanya proporsi pembagian laba atau keuntungan pada saat likuidasi atau pembubaran organisasi. Organisasi ini akan dikembangkan kembali saat pembubaran pengurusnya.

Mengikuti definisi PSAK no 45 tentang organisasi nir laba, maka dapat dikatakan bahwa organisasi GKI Sinode Wilayah Jawa Barat adalah organisasi nir laba, dan yayasan di bawahnya yang memenuhi definisi di atas adalah organisasi nir laba, meskipun dalam kenyataannya organisasi di bawah sinode seperti sekolah, universitas, rumah sakit beroperasi layaknya organisasi yang berorientasi laba untuk dapat bertahan hidup dan berkembang dengan sehat sesuai dengan tantangan jaman.

\subsection{Analisis Kegiatan Gerejawi}

Untuk organisasi GKI dalam menjalankan kegiatannya, dibagi dalam strata Sinode GKI, sinode Wilayah GKI, Klassis dan Jemaat Setempat. Untuk Sinode Wilayah Jawa Barat, telah mempunyai model yang dipakai di seluruh klassis sampai gereja lokal atau jemaat setempat, dengan sebutan PM-GKI atau Program Menyeluruh GKI, yang membagi semua kegiatan kedalam 4 bidang yang dibagi lagi menjadi komisi yang jumlahnya disesuaikan dengan kondisi dan kebutuhan jemaat setempat, yaitu: bidang Kesaksian dan pelayanan yang meliputi komisi Masyarakat dan komisi Pendidikan, yang bidang Persekutuan dan Keesaan yang meliputi komisi Kebaktian, Komisi Kesenian Gerejawi, Komisi Oikumene, komisi Pelawatan dan pelayanan kasih, bidang Pembangunan Jemaat meliputi komisi Anak, komisi Remaja, Komisi Pemuda, komisi Dewasa, komisi Lanjut Usia dan yang terakhir bidang Sarana Penunjang. Komisi-komisi tersebut juga dapat membagi diri menjadi seksi-seksi.

Dalam program kegiatannya, suatu jemaat setempat dapat mempunyai puluhan bahkan untuk gereja lokal yang besar kegiatan bisa sampai lebih dari ratusan kegiatan dalam program anggarannya per tahun.

Secara hukum badan hukum gereja sebagai Sinode dan badan hukum ini mendirikan yayasanyayasan yang bergerak di pelayanan pendidikan dasar, menengah dan pendidikan tinggi, juga yayasan-yayasan karitatif, seperti rumah jompo, yatim piatu, rumah duka dan lainnya. Dan secara hukum maka badan hukum ini dapat mempunyai harta (asset), berupa tanah, bangunan yang dibukukan dan dapat diperjual belikan mengikuti peraturan hukum yang berlaku.

\subsection{Menghilangkan Kegiatan Tak Bernilai Tambah Pada Kegiatan Gerejawi.}

Tujuan kegiatan dalam suatu kegiatan adalah mencapai suatu nilai, dalam kegiatan keagamaan tentu nilai spiritual. Nilai kegiatan dalam keagamaan dapat berbeda menurut latar belakang agama masing-masing, nilai tersebut bisa berupa pahala atau hal lainnya, yang sangat tergantung dari pemahaman teologis masing-masing agama. Dalam ke Kristenan sendiri, nilai kegiatan ibadah seperti Ekaristi di gereja Katolik, mungkin agak berbeda dengan 'perjamuan Kudus' di GKI. Di GKI sebelum aktivis diangkat sebagai pengurus komisi, yayasan atau sebagai panatua, diberikan pembinaan tentang nilai pelayanan dari kegiatan yang akan dilakukannya. Secara resmi GKI menyatakan motivasi pelayanan dalam kegiatan gereja adalah sebagai "ucapan syukur atas segala kasih karunia yang telah diterima dari Tuhan". 
Dalam menjalankan kegiatannya aktivis mengikuti panduan tersebut dengan tambahan atau pengurangan tafsir terhadap panduan tersebut.

Penentuan dan penyaringan terhadap program-program yang dilakukan komisi di gereja setempat GKI sangatlah longgar, hal tersebut ditentukan oleh para aktivis tersebut dan disetujui oleh Majelis Jemaat (Otoritas pengambil keputusan tertinggi di jemaat setempat) dengan sangat longgar sepanjang kegiatan tersebut tidak bertentangan dengan nilai-nilai Kristiani. Jadi kegiatan Olah raga, kegiatan kursus masak, demo masak, pelajaran bahasa Inggris, bahasa mandarin (yang banyak berpendapat sebagai kegiatan sekuler tidak memiliki nilai sakral) adalah hal yang dapat diterima dan biasa dipraktekkan sebagai program kegiatan yang di danai dengan anggaran gereja.

Seorang mantan anggota majelis memberikan kesaksian dalam pengalamannya sebagai panatua, bahwa ketika bendahara majelis yang melakukan saringan ketat pada kegiatankegiatan gereja maka pemasukan gereja yang didapat dari persembahan jemaat mengalami penurunan tapi ketika gereja tidak menahan anggaran yang harus dikeluarkan, maka penerimaan gereja dari persembahan melimpah. Lepas dari persetujuan dan validitas dari pernyataan tersebut, paling tidak ada pola pikir seperti itu dalam tubuh pengambil keputusan.

Evaluasi dan pertanggung jawaban terhadap kegiatan juga dilakukan dengan longgar. Dan ada nilai "kebersamaan" yang tidak berorientasi pada sasaran atau target, sehingga agak sulit untuk menilai apakah suatu kegiatan menambah nilai atau harus dihilangkan karena tidak memberi nilai tambah. Sehingga dapat dikatakan tema metode "Novaceli" yang dikembangkan secara umum yang dapat diterapkan pada semua organisasi nir laba, metode untuk menghilangkan kegiatan tak bernilai tambah dalam kegiatan gerejawi menjadi tidak relevan atau perlu pendalaman khusus untuk itu. Metode Novaceli yang telah dikembangkan seperti di tinjauan pustaka "menghilangkan NVA di industri jasa" hanya tepat diterapkan pada dibidang kesekretariatan, atau pelayanan administratif kesekretariatan gereja dan tidak untuk kegiatan gereja yang lain .

\subsection{Analisis Kegiatan Kegiatan Yayasan di Bawah GKI (Analisis YPTKM).}

Yayasan Perguruan Tinggi Kristen Maranatha adalah yayasan yang dibentuk oleh dua yayasan pendidikan, yaitu Yayasan Badan Pendidikan Kristen Penabur (BPK Penabur) dibawah Sinode GKI wilayah Jawa Barat dan Yayasan Badan Perguruan dan Pendidikan Kristen-Gereja Kristen Pasudan (BPPK - GKP).

Yayasan Perguruan Tinggi Kristen Maranatha, terdiri dari unsur Pembina, Pengawas dan Pengurus, khususnya mengelola Universitas Kristen Maranatha dan 2 Rumah Sakit Pendidikan, yaitu Rumah Sakit Gigi Mulut Maranatha dan Rumah Sakit Unggul Karsa Medika. Dalam kegiatannnya YPTKM ada dalam ranah kebijakan (policy) untuk keuangan dan Sumber Daya Manusia (kepegawaian) baik di Universitas maupun kedua Rumah Sakit Pendidikan.

Para dosen, dokter dan tenaga administrasi dan kerumahtanggaan di universitas dan rumah sakit pendidikan adalah karyawan YPTKM diatur dengan peraturan kepegawaian YPTKM. Kegiatan rutin yang dilakukan oleh pengurus YPTKM adalah setiap bulan mengadakan rapat komisi dan rapat pleno. YPYKM membentuk dua komisi yaitu komisi Akademik \& SDM dan Keuangan \& Sarana Prasarana. Hasil pembahasan tiap komisi dibawa ke rapat pleno Yayasan. Setiap tahun YPTKM mengadakan rapat kerja (Raker) yang membahas anggaran, renstra dari unit operasional di bawahnya, yaitu Universitas dan RS pendidikan. Salah satu tugas YPTKM adalah membuat Rencana Induk Pengembangan yang menjadi acuan unit di bawahnya untuk membentuk Rencana Strategis 5 tahun. Untuk melaksanakan setiap kebijakan dan keputusan YPTKM, maka diangkat direktur pelaksana dengan tugas membawahi kesekretariatan 
Yayasan dan melaksanakan program-program yayasan di luar yang dilimpahkan pada UKM atau RS Pendidikan, seperti program perumahan karyawan. Selain itu berkoordinasi dengan UKM dan RS Pendidikan dalam memantau keuangan dan kepegawaian. Direktur Pelaksana melaporkan pekerjaannya pada YPTKM dalam rapat pleno.

\subsection{Analisis Kegiatan Unit di Bawah Yayasan (Universitas Kristen Maranatha)}

Organisasi Universitas Kristen Maranatha memiliki 9 Fakultas, 28 Program Studi sebagai ujung tombak universitas dalam menjalankan kegiatan tri darma perguruan tinggi, yaitu: pendidikan, penelitian dan pengabdian kepada masyarakat. Untuk menunjang kegiatan inti, universitas melengkapi diri dan Satuan, Unit, Badan, Lembaga, Direktorat dan Bagian. Saat dilakukan penelitian terdapat 2 Satuan (yaitu Satuan Penjaminan Mutu, Satuan Pengawasan Internal), satu Badan (Badan Pelayanan Kerohanian), dua lembaga (LPPM-Lembaga Penelitian Pengabdian pada Masyarakat dan LEDU-Lembaga Edukasi), satu Unit yaitu Unit Pelaksana Teknis - UPT Perpustakaan, 9 Direktorat dan 24 bidang di bawah direktorat dan lembaga.

Program kerja yang dilakukan oleh Universitas ada ratusan dan setiap program kerja terbagi menjadi berbagai kegiatan. YPTKM mengangkat pimpinan Universitas - Rektor yang bertanggung jawab untuk jalannya kegiatan Universitas Kristen Maranatha sesuai dengan Rencana Strategi UK Maranatha dan Anggaran UK Maranatha. Untuk analisis maka peneliti membagi pembentukan kegiatan UK Maranatha dalam dua bagian, yaitu strategis dan operasional.

Rencana Strategis UK Maranatha yang disusun dan diusulkan oleh pimpinan UKM untuk masa jabatan setiap 5 tahun, direkomendasikan oleh Senat Universitas dan disetujui YPTKM. Pembentukan Rencana strategis mengacu pada Rencana Induk Pengembangan yayasan dengan melakukan kajian evaluasi diri dan analisis SWOT sehingga merumuskan issue-issue strategis. Dari Issue Strategis ini ditetapkan Tujuan dan Sasaran Strategis yang spesifik dan Strategi Pencapaian nya, Dilengkapi dengan Indikator Pencapaian Strategi yaitu alat ukur sejauh mana sasaran-sasaran tersebut tercapai dan juga dilengkapi dengan penanggung jawab $(P I C=$ Person in Charge $)$. Bisa dikatakan sasaran-sasaran strategis yang ditetapkan memenuhi kriteria sasaran yang ideal yaitu spesifik, terukur, dapat dicapai, realistik dan terikat waktu (SMART = Spesific, Measureable, Realistic, Achievable, Time Bounded).

Untuk mencapai sasaran strategis tersebut dibuat program kerja strategis dengan penanggung jawab yang juga akan menurunkan dan menyebarkannya ke strata dibawah universitas, yaitu Fakultas dan direktorat dibawah universitas.

Dengan mengikuti template dan langkah yang sama di lapisan Universitas, proses pembentukan Rencana Strategis dilakukan di Fakultas di bawah Universitas.

3.8 Menghilangkan Kegiatan Tak Bernilai Tambah Pada Kegiatan Yayasan (YPTKM). Kegiatan yang dilakukan oleh Yayasan berada di ranah strategis yaitu menentukan arah untuk perkembangan, keberlanjutan (sustainability) unit kerja di bawahnya (Universitas, Rumah Sakit Pendidikan). Effektivitas dari Yayasan lebih ditentukan oleh keputusan dan kebijakan yang dibuatnya dari pada kegiatannya. Apakah keputusan dan kebijakan yang dibuatnya akan membuat unit yang di bawahnya berkembang, atau mampu bertahan dalam tantangan di luar, baik persaingan, krisis (seperti krisis pandemi Covid 19 belakangan ini). Penilaian ini dilakukan sendiri oleh Yayasan dengan perangkat yang dimiliki nya seperti badan pembina dan badan pengawas, belum tentu suatu yayasan akan bersedia untuk dinilai oleh pihak di luar dirinya sendiri..

Metode Novaceli yang telah dikembangkan seperti di tinjauan pustaka "menghilangkan NVA di industri jasa" hanya tepat diterapkan pada dibidang kesekretariatan, atau pelayanan 
administratif kesekretariatan pada direktorat pelaksana Yayasan dan tidak sesuai untuk kegiatan yayasan yang lain.

\subsection{Menghilangkan Kegiatan Tak Bernilai Tambah Pada Kegiatan Universitas.}

Proses perencanaan pada organisasi Universitas menghasilkan program kerja dan kegiatan sampai ratusan. Evaluasi untuk menilai efektivitas kegiatan dilakukan oleh dua satuan, yaitu: Satuan Penjaminan Mutu (SPM) dan Satuan Pengawas Internal. Satuan Penjaminan Mutu memonitor dan mengevaluasi sejauh mana sasaran mutu tercapai melalui kegiatan Audit Internal, dan Satuan Pengawas Internal melihat dan mengevaluasi apakah program kegiatan yang sudah direncanakan sudah dilakukan secara baik. Lebih pada apakah program kerja dilakukan dan seberapa jauh anggaran terserap.

Metode Novaceli yang telah dikembangkan seperti di tinjauan pustaka "menghilangkan NVA di industri jasa" dapat segera diterapkan untuk kegiatan operasional namun tidak untuk kegiatan strategis strata atas. Penelitian yang lebih mendalam dalam tema dan semangat "menghilangkan kegiatan yang tidak menambah nilai"tepat dan perlu dalam momentum disrupsi pandemi Covid-19.

\section{Kesimpulan}

Hasil penelitian ini menyimpulkan untuk organisasi gereja setempat, pada strata strategis tema Novaceli tidak relevan. Untuk strata operasional metode Novaceli untuk industri jasa dapat diterapkan, yaitu pada kegiatan pelayanan administrasi dan kebutuhan surat keterangan bagi jemaat.

Untuk organisasi Yayasan (YPTKM), metode Novaceli untuk industri jasa yang telah dikembangkan seperti di tinjauan pustaka "menghilangkan NVA di industri jasa" hanya tepat diterapkan pada dibidang kesekretarisan, atau pelayanan administratif kesekretarisan pada direktorat pelaksana Yayasan dan tidak sesuai untuk kegiatan yayasan yang lain .

Untuk organisasi Universitas, metode Novaceli yang telah dikembangkan seperti di tinjauan pustaka " menghilangkan NVA di industri jasa" dapat segera diterapkan untuk kegiatan operasional namun tidak untuk kegiatan strategis strata atas.

Untuk mendapat generalisasi metode novaceli organisasi nir laba jenis lain, seperti Lembaga Swa Daya (LSM/NGO). organisasi karitatif perlu diadakan penelitian lanjut.

Kesimpulan ini dapat berkembang dengan penelitian lanjutan, sifat kesimpulan tidak definitif ini merupakan ciri khas dari penelitian kualitatif.

\section{Daftar Pustaka}

Bercaw, R. G. (2013) Lean leadership for healthcare transformation. Boca Raton: CRC Press.

Bohan, R. (2012) The first rule of lean culture change. Tersedia pada: http://www.industryweek.com/lean-six-sigma/first-rule-lean-culture-change (Diakses: 27 February 2017)

Cardon, N., \& Bribiescas, F. (2015) 'Respect for people: the forgotten principle in lean manufacturing implementation', European Scientific Journal, 11(13), 45-61.

Cohen, L. L. Manion and K. Morrison (2011) Research methods in education, 7th edition London: Routledge, xii, ISBN 13:978-0-415-58336-7 (pbk)

Draft Rencana Strategis Universitas Kristen Maranatha 2020-2024. 
Draft Renstra Fakultas Teknik Universitas Kristen Maranatha 2020-2024

Bond, C., Pelleter, L. (2013) 'Using value added analysis to improve an emergency department', Health Care System Process Improvement Conference 2013, Society for Health System

Heathfield, S. M. (2016) How to demonstrate respect in the workplace [Online]. Tersedia pada: $\quad$ https://www.awpnow.com/main/2017/02/08/use-these-tips-to-create-a-respectfulworkplace/ (Diakses: 27 Februari 2017).

Hendartini, J., Meliala, A., Firman, Endartiwi, S. S., \& Bismantara, H. (2016) Evaluasi pelatihan value based service in healthcare with lean management dengan metode evaluasi Kirkpatrick (who method for training evaluation), Yogyakarta.

Storfell, J., et al. (2009) 'Non value added time - the million dollar nursing opportunity', Journal of Nursing Administration, Volume 39, Number 1, pp 38-45

Usman, I., Andriyana, M. (2017) 'Lean hospital manajemen, studi empirik pada layanan gawat darurat', Jurnal Manajemen Teori dan Terapan, Volume 10, No.3.

Kolarik, William J. (1995) Creating Quality : concepts, systes, strategies, and tools", McGraw-Hill series in industrial engineering and management science, McGraw-Hill international editions.

Mcmanus, H. (2012) Lean academy health care "application of lean health care processes- a complex system perspective, Lean Academy Health Care

Liker, J. K. (2004) The Toyota way: 14 management principles from the world's greatest manufacturer history, New York: McGraw Hill.

Lord, Z., \& Smith, L. (2012) Bringing lean to life. NHS Improvement.

Nicholas, John (2018) Lean production for competitive advantage. Taylor \& Francis Group, LLC.

Lawrence, N. W. (2014) Social research methods: qualitative and quantitative approaches. $7^{\text {th }}$ edition. Pearson New International Edition.

Pande, P.S., et al. (2000) Six sigma way. Mc Graw Hill

Radnor, Z. (2012) Why lean matters. Advanced Institute of Management Research.

Rubrich, L. (2009) Developing a lean culture - an elements checklist [Online]. Tersedia pada: http://www.reliableplant.com/Read/26766/developing-lean-culture-elements (Diakses: 27 Februari 2017)

Saunders, M., et al. (2007) Research method for business students. Pearson Education Limited, Prentice Hall Financial Times.

Sobek II, D. K. (2011) 'Lean healthcare implementation: critical success factors', 61 st Annual IIE Conference and Expo Proceedings, Arena; Boeing; et al.; FedEx Ground; ISE-al.NC Stat. 
JOURNAL OF INTEGRATED SYSTEM VOL 4. NO. 2, DESEMBER 2021: 168-180

Sfandyarifard, E. (2010) 'Lean method, a solution to problem in hospital', Proceedings: TG65 and W065 - Special Track, 18th CIB World Building Congress, Salford, United Kingdom.

Yin, R.K., Campbell, D. T. (2018) Case study research and applications: design and methods. $6^{\text {th }}$ edition. Cosmos Corporation, SAGE Publication Inc. 